\title{
Consumers preference for rabbit meat as a source of animal protein in selected Local Government Areas in Rivers State
}

L.A.F. Akinola and M.O. Ironkwe

Department of Animal Science and Fisheries, Faculty of Agriculture, University of Port Harcourt, P.M.B. 5323 Port Harcourt.

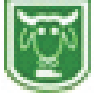

Corresponding Author: letorn_akinola@yahoo.com

\begin{abstract}
The study was designed to determine consumer's preference for rabbit (Oryctolagus cuniclus) meat with respect to its production and consumption in Khana, Gokana, Tai and Eleme Local Government Areas (LGAs) making up the Ogoni Kingdom in Rivers State, Nigeria. A sample of 80 respondents $(20$ per LGA) were selected and interviewed using structured questionnaires. The data collected were analyzed using descriptive statistics such as frequency counts and percentages. The result indicated that the availability of animals reared or hunted in the LGAs apart from poultry were in the order of goat (47.5\%), sheep (28.8\%), rabbit (11.3\%), grass-cutter (8.8\%) and monkey (3.8\%). Producer's preference for rearing animals also followed a similar order. Demographic characteristics of the rabbit farmer showed that most of them were males (above 50 years) who had tertiary education and kept 1-20 rabbits both for family consumption and sales. Although more of the respondents (47.5\%) were aware of rabbit as an animal, goats were more domesticated in the area but they indicated their readiness to increase the production and consumption of rabbit (77.5\%). Further investigation revealed that consumers had high preference for goat and sheep meat, medium preference for rabbit and grass-cutter meat and low preference for meat from monkey. Among the factors identified that were capable of boosting rabbit production were the rich vegetation in the area, the ability of the rabbits to survive on roughages with little or no proprietary feeds, low cost of production, short gestation period and the high prolific nature of rabbits. It is therefore believed that with the good knowledge of goat and sheep production by most of the respondents in the area, which has some similarities with that of rabbit production, any effort targeted at improving the people's preference for rabbit production and consumption in the LGAs (through radio jingles or seminars) will increase animal protein intake, create jobs, alleviate poverty and enhance rural livelihood.
\end{abstract}

Key words: Rabbit, meat, consumer preference, animal protein

\section{Introduction}

Rabbit had since been identified as an economic livestock for small-scale rural farmers/dwellers, capable of producing about enough meat per meal solely to meet the animal protein requirement of a medium - sized family (Abdulmalik, 1994, Hassan and Owolabi, 1996). A lot of effort should therefore be put into popularizing the rearing of rabbits among rural populace and other low income groups, because it is one source of animal protein which holds a lot of promise for increasing the supply and intake of animal protein among these classes of people. Rabbits multiply and grow rapidly producing high quality meat and capable of utilizing very cheap feed. They can survive and thrive on a wide range of fresh or preserved grasses, shrubs and 
leaves (Ayoade et al., 1985, Carew et al., 1989) that are not consumed by humans. Literature shows that the white meat of rabbit is nutritious easily digestible and extremely low in cholesterol and sodium levels (Omole et al., 2005). According to Damron (2006), a cooked piece of rabbit meat is high in protein $(56 \%)$, low in fat $(9 \%)$ low in cholesterol, sodium and colories $(8 \%)$ and contains $28 \%$ phosphorus, $13 \%$ iron, $16 \%$ zinc, $14 \%$ riboflavin, $6 \%$ thiamin, $35 \% \mathrm{~B}_{12}$ and $48 \%$ niacin. Despite these good qualities of rabbit, there are still indications that most people residing in Rivers state, Nigeria, do not seem to prefer the rabbit animal for consumption. This had resulted to low production and neglect of its meat by some. This survey was therefore carried out to ascertain consumers' preference for rabbit meat as a source of animal protein for the rural populace in selected LGAs in Rivers State.

\section{Methodology \\ Description of the study area}

Ogoniland consist of four Local Government Areas (LGAs) out of the 23 LGAs in Rivers State, Nigeria. These are: Khana (consisting of Nyo-khana, Kenkhana and Babbe areas), Gokana, Tai and Eleme LGAs (Figure 1). The area occupied by the Ogoni lies approximately between latitude $4.05^{1}$ and longitude $7.308^{1}$ East. It is bounded on the West by the Ikwerre, on the North and East by the Imo River and on the South by the Andoni. It covers about 404 square kilometers. It forms part of the coastal plain terrace which appears at a gently sloping plateau intersected by a few deep valleys which carry water intermittently (Nwoke, 2012). Ogoni is a predominantly agricultural economy where the increasing population has led to the clearing of most parts of the rainforest that once covered the area.

Four (4) autonomous communities were selected in each LGA for the study. These communities were: Wiiakara, Boue, Kono and Okwali in Khana LGA, Biara, Nweol, Bormu and Bodo in Gokana LGA, Sime, Barayira, Norwa and Koro-Koro in Tai LGA and Akpajo, Eteo, Onne and Nchia in Eleme LGA. Five (5) respondents were randomly selected from each of the community, making up a total of 80 respondents from the four LGAs. Data collection was done through structured questionnaires administered to the respondents. Completed questionnaires were retrieved and analyzed through descriptive statistics using frequency counts and percentages.

\section{Results}

Result from the study (Table 1) indicated that more males $(53.8 \%)$, above 50 years were involved in rearing rabbits in the four LGAs sampled. Most of the respondents $(43.7 \%)$ had tertiary education. The result also showed that more of the respondents (53.8\%) kept 1-20 rabbits for both consumption and sales.

The responses obtained from the respondents on the availability of animals (Table 2), indicated that a greater number of the farmers (47.5\%) agreed that goats were more available while moneys were the least available (3.8\%). Most of the respondents $(43.7 \%)$ agreed that they were aware of rabbit as an animal but preferred rearing goat. A higher percentage of them $(77.5 \%)$ indicated their readiness to increase production and consumption of rabbit.

Consumers preference for meat from different animals (Table 3), showed that the meat from goat and sheep were highly preferred followed by rabbit and grasscutter (medium preference) while the monkey meat was the least preferred (low 
Figure 1: Map of Ogoniland in Rivers State, Nigeria

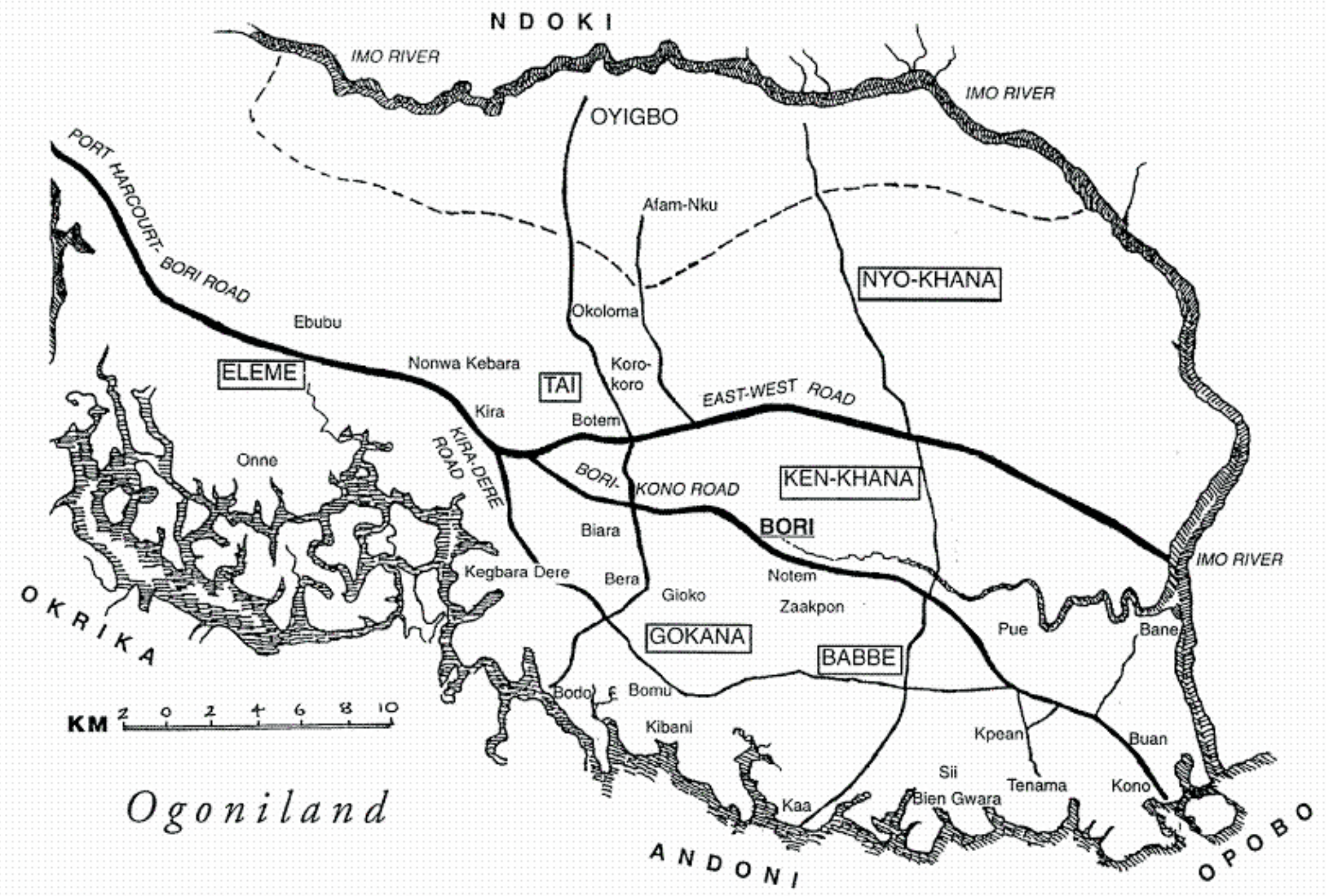

SOUrCe: MITEE RESEARCH FOUNDATION $\odot 1995$ 
Table 1: Demographic characteristics of rabbit farmers in Khana, Gokana, Tai and Eleme LGAs in Rivers State.

\begin{tabular}{|c|c|c|c|}
\hline$S / N$ & Variables & Frequency & Percentages (\%) \\
\hline \multirow[t]{4}{*}{1} & Sex of Farmers & & \\
\hline & Females & 43 & 53.8 \\
\hline & & 37 & 46.2 \\
\hline & Age & & \\
\hline \multirow[t]{5}{*}{2} & $31-40$ & & \\
\hline & $41-50$ & 11 & 13.8 \\
\hline & $>50$ & 18 & 22.5 \\
\hline & & 51 & 63.8 \\
\hline & Level of Education & & \\
\hline \multirow[t]{5}{*}{3} & Primary & & \\
\hline & Secondary & 20 & 25.0 \\
\hline & Tertiary & 25 & 31.3 \\
\hline & & 35 & 43.7 \\
\hline & Farm size(No. of Rabbits) & & \\
\hline \multirow[t]{6}{*}{4} & $1-20$ & & \\
\hline & $21-40$ & 43 & 53.8 \\
\hline & $41-60$ & 20 & 25.0 \\
\hline & $61-80$ & 10 & 12.7 \\
\hline & & 7 & 8.7 \\
\hline & Purpose of rearing rabbit & & \\
\hline \multirow[t]{4}{*}{5} & $\begin{array}{l}\text { Consumption } \\
\text { (Cheaper protein source) }\end{array}$ & & \\
\hline & Sales & 29 & 36.3 \\
\hline & Both & 16 & 20.0 \\
\hline & & 35 & 43.7 \\
\hline
\end{tabular}

preference).

Some of the factors identified by the respondents that could boost rabbit production (Table 4) in the study area included: the rich vegetation of the area, the ability of rabbits to thrive on roughages with or without concentrate feed, low cost of production, short gestation period, and the prolific and docile nature of rabbits. More of the respondents agreed that goats were mostly domesticated in the area but radio jingles can be used as the major training method to boost rabbit production and consumption in the four LGAs.

\section{Discussion}

The higher number of males who kept rabbits in this study tallied with the report of Ajimohun et al. (2008) who reported that more males were involved in the rearing of sheep and goats in Bauchi state, Nigeria. The age of the farmers which were mostly above 50 years could be attributed to their need for cheaper sources of protein to maintain their families and for sales. The higher level of tertiary education attained by most respondents could be an indication for easy training of the respondents in desired skills needed for livestock operation as reported by Farinde and Ajayi, (2005). The small number of rabbits reared for sales and consumption by majority of the farmers may have resulted from their tendency of rearing more goats and sheep than other animals.

The availability of more goats in the study area could be attributed to the rich 
Table 2: Responses on Animal availability and awareness in Khana, Gokan a, Tai and Eleme LGAs in Rivers State.

\begin{tabular}{lll}
\hline Items & Frequency & Percentages (\%)
\end{tabular}

Availability of animals

In the 4 LGAS

Goat $\quad 38 \quad 47.5$

$\begin{array}{lll}\text { Grass-cutter } & 7 & 8.8\end{array}$

$\begin{array}{lll}\text { Monkey } & 3 & 3.8\end{array}$

$\begin{array}{lll}\text { Rabbit } & 9 & 11.3\end{array}$

$\begin{array}{lll}\text { Sheep } & 23 & 28.8\end{array}$

Awareness of rabbit meet

and availability for sale.

$\begin{array}{lll}\text { Yes } & 29 & 36.3\end{array}$

$\begin{array}{lll}\text { No } & 35 & 43.7\end{array}$

$\begin{array}{lll}\text { Undecided } & 16 & 20.0\end{array}$

Readiness to increase

Production and consumption

of rabbit

$\begin{array}{lll}\text { Yes } & 62 & 77.5\end{array}$

$\begin{array}{lll}\text { No } & 12 & 15.0\end{array}$

$\begin{array}{lcc}\text { Undecided } & 6 & 7.5\end{array}$

Source: computed from Survey data

Table 3: Position of meat from different animals on the preference scale of con sumers.

\begin{tabular}{|c|c|c|c|c|}
\hline Species & High preference $(H P)$ & $\begin{array}{l}\text { Medium } \\
\text { (MP) }\end{array}$ & preference & Low preference $(L P)$ \\
\hline Goat & Yes & & - & - \\
\hline Grass-cutter & - & & Yes & - \\
\hline Monkey & - & & - & Yes \\
\hline Rabbit & - & & Yes & - \\
\hline Sheep & Yes & & - & - \\
\hline
\end{tabular}


Table 4: Factor capable boosting rabbit production in the area

\begin{tabular}{|c|c|c|}
\hline Items & Frequency & Percentages \\
\hline \multicolumn{3}{|l|}{ Vegetation } \\
\hline Rich & 77 & 96.3 \\
\hline Poor & 3 & 3.7 \\
\hline \multicolumn{3}{|l|}{ Feeding/ survival of rabbits } \\
\hline On proprietary feed al one & 2 & 2.5 \\
\hline On both & 10 & 12.5 \\
\hline \multicolumn{3}{|l|}{ Cost of production } \\
\hline High & 15 & 18.7 \\
\hline Low & 65 & 81.3 \\
\hline \multicolumn{3}{|l|}{ Gestation period } \\
\hline Long (30-31 days) & 18 & 22.5 \\
\hline Short (30-31 days) & 62 & 77.5 \\
\hline \multicolumn{3}{|l|}{ Productivity/nature } \\
\hline Highly prolific and docile & 69 & 86.3 \\
\hline Not prolific and docile & 11 & 13.7 \\
\hline \multicolumn{3}{|c|}{ Knowledge of other animal production } \\
\hline Goat & 48 & 60.0 \\
\hline Sheep & 32 & 40.0 \\
\hline \multicolumn{3}{|c|}{ Training methods to boost rabbit production } \\
\hline Seminars & 38 & 47.5 \\
\hline Radio jingles & 42 & 52.5 \\
\hline
\end{tabular}

vegetable in the study area. The ability of goats to adapt to a wide range of environment as well as utilizing wide varieties of plant species for food and converting such low cost feed resources to valuable products (meat, milk and skin) had been reported by Rege, (1994). The low availability of monkey had already been reported by Kalio et al. (2007). They reported that meat from monkey was the least available animal protein source among the Ekpeye people in Rivers State. The readiness of most respondents to increase the production and consumption of rabbit may be attributed to the enlightenment on rabbit production and its merits received in the course of completing the questionnaires.

The trend observed in the preference for meat which gave high preference to meat from goat and sheep and medium preference for rabbit and grass-cutter meat may be due to the more availability of goats and sheep compared to rabbits in the study area.

The rich vegetable in the study area depict the geographical location of the Ogonis' in the tropical rain forest area in Rivers State. The high ability of the rabbits to feed and survive on roughages alone and the low cost of rabbit production in the study area may be linked to the availability of both grasses 
and legumes usually found on a typical high rainforest zone. The acknowledgement of the short gestation period of rabbits by respondents, with its highly prolific and docile nature, which make them amenable to handle by all categories of people, including women and children could be as a result of their knowledge of the longer gestation period and the productive nature of goats and sheep.

With the good knowledge of goat and sheep production in the area, most of the respondents agreed that the use of radio jingles and seminars will lead to an increase in rabbit production, its awareness and preference for meat.

\section{Conclusion}

This study had shown that rabbit production and consumption could be increased and even preferred to when compared to other animals in Khana, Gokana, Tai and Eleme L.G.A.s in Rivers State. The readiness of respondents to increase rabbit production is of major interest and need to be encouraged. This study confirmed that enlightening the inhabitants through seminars and radio jingles about the benefits of rabbit production will greatly increase animal protein supply, consumption and income generation of the rural populace.

\section{Reference}

Abdulmalik, M.E.1994. Rabbit production. In Okaiyeto, P.O Ndubuisis, A.H. and Okoh, A.E. (eds). Advanced Animal Husbandary Practices for Subject Matter Specialists in the ADPs. Training Manual for FACU/NAPRI, workshop, Zaria, 13-17 December, 1994.

Ajimohun F.F., Adegboola, T.A., Amos, T.T. and Bawa, G.S. 2008. Factors affecting herd size among small scale sheep and goat farmers in Bauchi Local
Government Area of Bauchi State. Proceedings of the $13^{\text {th }}$ Annual Cong. OfASAN, Abu, Zaria pp. 734-737.

Akinola L.A.F. And George, O.S. 2008. Small-scale family poultry production as a substantial source of animal protein in selected Local Government Areas of Rivers State. Journal of Agriculture and Social Research. Journal of Agriculture and Social Research (JASR). 8(2): 47-50.8(2).

Ayoade, J.A., Makhambera, T.P.E and Kayange, M. 1985. Studies in the nutrition of rabbit in Malawi. I. Apreliminary studies on the chemical composition of the control Malawi plant eaten by rabbits. Journal Applied Rabbit Research. 89(2): 81-82.

Carew, S.N., Ayoade, J.A. and Zungwe, E.N. 1989. Proximate composition of plants observed being fed to rabbits in Benue State of Nigeria. Journal Applied Rabbit Research. 12: 169-170.

Damron, W.S. 2006. Introduction to Animal Science, Global, Biological Social and Industry Pespective. $3^{\text {rd }}$ Ed. Pearson EDu. Inc. U.S.A. pp. 216.

Farinde, A.J and Ajayi, A.O. 2005. Training needs of women farmers in livestock production: implications for rural development in Oyo State of Nigeria. Journal of Social Science 10(3): 159-164

Hassan, W.A. and Owolabi, R.O 1996. Production performance of domestic rabbits in semi-arid zones of Nigeria. Proceeding of the $6^{\text {th }}$ World Rabbit Congress, Toulouse, France, 3: 359363.

Kalio, G.A., Etela, I and Ginika, V.E 2007. Rabbit meat as alternate animal protein source in selected rural communities of Rivers State. Proceeding $32^{\text {nd }}$ Annual Conference of the Nigeria Society for Animal 
Production. 32:415-417.

Nwoke, M.B. 2012. Impact of cultural value system on the personality development of Ogoni Adolescents. Asian Social Science. 8(3): 100-112.

Omole, A.J., Omuet, O. and Ogunleke, O.J.2 2005 . P e r formance characteristics of weaned rabbits fed graded levels of dry cassava peel fortified with soy-corn residue basal diet. Journal of food, Agriculture and
Environment. 3:36-38.

Rege, J.E.O. 1994. Indigenous small ruminants: A case for characterization and improvement. In: Lebbie, S.H.B., REy, B.and Irungu, E.K. (eds). Small Ruminant Research and Development in Africa. Proceeding $2^{\text {nd }}$ Biennial Conference of the African Small Ruminant Research Network, AICC, ILCA, Addis Ababa, Ethiopia. 2:205211.

Received: 20th September, 2008 Accepted: 26th November, 2012 